\title{
Pesticides and child's health in France
}

Cécile Chevrier, Rémi Béranger

Univ Rennes, Inserm, Irset (Research Institute for Environmental \& Occupational Health)) UMR 1085, Rennes, France

Corresponding author: cecile.chevrier@inserm.fr

Irset, 9 avenue Pr Léon Bernard, 35000 Rennes, France

\begin{abstract}
Purpose of review: The use of pesticides is predominant in agriculture, inducing environmental contamination, and has been extended to the domestic sphere. In France, $>500$ pesticides were authorized for use in 2009; given their various toxicological properties, there are legitimate concerns about the possible consequences for child health. This review summarizes the recent French studies of good quality dealing with pesticides and child health.

Recent findings: Three cohorts (mother-child, retrospective) and two case-control studies have been conducted in the last decade. Using various instruments for exposure assessment including biomarkers, they have suggested alterations of subclinical health parameters at birth, increased risk of otitis at age 2, and increased risk of several types of childhood cancer. However, there was no adverse neurodevelopmental outcomes at 6 years of age following prenatal exposure to pesticides.

Summary: Both agricultural and domestic pesticides might be involved in such adverse health outcomes. Similar studies are lacking in Europe. Studies on fungicides and child health are scarce.
\end{abstract}

\section{Keywords}

Pesticides, environmental exposure, pregnancy, growth, neurodevelopment, cancer 


\section{Introduction}

Synthetic pesticides are chemicals designed to affect living systems (1). They are used worldwide, predominantly in agriculture, to enhance food production, by controlling or destroying organisms harmful to crops. Pesticides have also been used in the wood and textile industries and have been shown to be potentially useful in other specific areas, such as combating vector-borne diseases. Pesticide use has also been extended to the individual domestic context, to deal with various pests, such as weeds, rodents and fungi, and to human and animal medicine, to treat mycosis, fleas and ticks. The term "pesticide” encompasses encompass a huge number of molecules with various toxicological properties and being present in mixtures. There has long been concerns about the possible consequences for human health of this complex and widespread exposure to pesticides of the general population.

Given the possible reprotoxicity, neurotoxicity or endocrine-disrupting properties established or suspected for numerous pesticides, we review here association studies dealing with current-use pesticides and child health. We focus on the recent French context, in which more than 500 active substances were authorized for use in $2009\left(2^{* *}\right)$. It does not, therefore, include organochlorine pesticides, even though the population is still exposed to background environmental levels and health consequences cannot be ruled out. In particular, there was a specific environmental contamination of the soil and water that occured in the French West Indies between 1973 and 1993, due to use of the organochlorine insecticide chlordecone to fight banana root borer infestations. It resulted in exposure of the general population in these areas, likely by ingestion of contaminated food, and for which possible health consequences for children were identified in a local mother-child cohort, not considered in this minireview $(3,4,5)$.

\section{Pesticide usages in France and population exposure}

In France, 110,000 tons of pesticides were used annually in the late 1990s (6). Pesticide use subsequently decreased, to 76,000 tons in 2004, mostly due to the introduction of new synthetic pesticides allowing the application of lower doses per hectare (6). Pesticide use has since remained stable $( \pm 10 \%)$, with $>90 \%$ destined for agricultural activities. France was ranked as the $8^{\text {th }}$ largest pesticide consumer in Europe in 2014 when considering the mean application rates of $2.7 \mathrm{~kg} /$ ha (7). According to the national sales data for agricultural pesticides in 2016, 45\% of the pesticides purchased were fungicides (including copper and sulfur), 41\% were herbicides and 5\% were insecticides. Agricultural activities are diverse in France, extending from wheat and other cereal crops, to husbandry and vineyards. Agriculture occupies half the total area of the country, making use of the rich soils and clement meteorological conditions.

Synthetic pesticides have been commonly used for seven decades in France, inducing continuing environmental contaminations. Water systems have been routinely monitored in France since 1998, and almost all surface and ground waters have been shown to be contaminated with pesticide residues, including a number of molecules that are now banned (8). In 2006, a total of 243 pesticide residues, mostly herbicides and their metabolites, was found in French rivers ( $\left.2^{* *}\right)$. Monitoring of air contamination by pesticides has not been regulatory in France, and until now, depends on initiatives of local air quality organizations (9). Pesticides were detected in $12 \%$ of 
the 100,000 air measurements combined from 2002 and 2006, representing 114 different substances $\left(2^{* *}\right)$. Indoor contamination was investigated in samples of air and dust from homes, in several studies, all of which reported the presence of pesticides, some of which were not detected in outdoor air (2**). At last, total diet studies (TDS) have been set up as part of a national initiative, to analyze pesticide residues in food, and to estimate the dietary exposure of the French population $(10,11)$. The second TDS, conducted between 2006 and 2011 showed that one third of the 1235 food items tested contained pesticide residues. Overall, 73 substances were detected out of 283 of interest, mostly insecticides, acaricides and fungicides (10).

The French general population is exposed to multiple current-use pesticides and their metabolites. However, knowledge of this exposure remains incomplete and has focused on few specific chemical families, such as organophosphorus (OP) and pyrethroid (PYR) insecticides and triazine herbicides. In early 2000's a few research studies based on biological monitoring provided the first solid data for exposure in the general population, including children and pregnant women $(12,13)$. Ubiquitous exposure to OP and PYR insecticides was confirmed for the adult population in 2006-2007 (14), and the 2011 survey showed ubiquitous exposure to PYR insecticides, less frequent exposure $(<30 \%)$ to OP insecticides and rare exposure to triazine compounds $(<1 \%)$ in pregnant women in France, consistent with the prohibition of atrazine usage in Europe in 2003 (15). These studies provided clues to possible determinants of pesticide exposure in the general population. National efforts have since been made to assess the exposure of the population to pesticides through domestic usages with an on-going nationwide study including French overseas territories in which products against insects are likely to be frequently used (16), and, more recently, through living proximity to treated crops, including vineyards in particular.

\section{Pesticides and developmental health in France}

\section{Three cohort studies focusing on exposure during pregnancy}

Two mother-child cohorts and one retrospective cohort in the last two decades have investigated this issue (Table 1). According to the developmental origins of health and diseases hypothesis (DOHaD), they have focused on the exposure during pregnancy and its possible effects on developmental health, from prenatal life to childhood. The health outcomes of interest related to fetal growth, metabolic disorders, otolaryngological conditions and behavioral and cognitive development, and might be subclinical endpoints underlying functional alterations.

The PELAGIE (Perturbateurs Endocriniens: Étude Longitudinale sur les Anomalies de la Grossesse, l'Infertilité et l'Enfance) cohort enrolled 3,421 pregnant women at their first prenatal visit ( $<19$ weeks of gestation), from 2002 to February 2006, in Brittany. This region, in the north west of France, has large areas devoted to vegetable production, but its agricultural activities also include pig, poultry, and dairy farming, requiring the production of corn or other fodder crops (62\% of the total area under agriculture). The children, their health and environment were followed, at birth and then at the ages of two, six and 12 years. Outcomes of interest were assessed from medical records at birth, self-administered questionnaires, measurements in biological samples or from clinical examinations specific to the cohort, including neuropsychological examinations by trained psychologists. Exposure was assessed with selfadministered questionnaires, in both retrospective and prospective ways $(17,18)$, by 
determinations of the chemicals present in maternal urine samples collected during pregnancy $(18,19 *, 20,21,22,23)$ and with spatialized soil occupancy data (municipality scale (17) or 250mscale (18)). More details are provided in Table 1.

The MecoExpo cohort was conducted in Picardie, a region in which $69 \%$ of the total area is devoted to agriculture, principally the cultivation of diverse cereals and rape seed. The cohort enrolled 993 mother-child pairs from 11 maternity wards, between January 2011 and January 2012. Health data for the children at birth were collected from medical records. Exposure was assessed through self-administered questionnaires completed by the mothers just after the delivery (24). Meconium samples were also collected and stored for subsequent pesticide determinations (25).

Finally, a retrospective cohort study making use of the regulatory determination of pesticides in drinking water was performed in Deux-Sèvres, a region in which agricultural activity is predominant (76\% of the total area) and based essentially on livestock, mostly sheep and goats. Health data at birth were collected from the infant health certificates mandatory at the $8^{\text {th }}$ day of life. Exposure was assessed specifically during the second trimester of pregnancy, at municipality scale. The principal exclusion criteria were delivery by cesarean section (17\%) and municipalities with several suppliers of drinking water (18\%). The final study cohort thus concerned 11,466 births in 2005-2009 (26), and 13,654 in 2005-2010 (27).

\section{The results: from fetal growth to neurodevelopment}

Maternal occupational exposure to pesticides was not associated to anthropometric parameters at birth, or a risk of preterm birth, whereas paternal occupational exposure was found to be associated with a shorter duration of gestation and a higher risk of preterm birth in the MecoExpo cohort (24).

Lower birth weight was associated in both the PELAGIE and the MecoExpo cohorts with prenatal use by the household of pesticide products, for the treatment of plants, in particular (17, 24), and veterinary antiparasitic products against fleas and ticks (24). Mean head circumference at birth was also smaller in families that reported to have treated plants with insecticides during the prenatal period (17). Human antiparasitic products, likely to be lice shampoos, was associated with higher mean of birth weight (24). It should be noted that part of shampoos for treating lice do not contain pesticide molecules. No association was observed between household pesticide use during pregnancy and the gestational duration or prematurity in the MecoExpo cohort (24), or the risk of otitis in the child at the age of two years in the PELAGIE cohort (18).

In Brittany, based on soil occupancy data, living close to crops likely to be treated with insecticides during pregnancy was associated with a reduced head circumference on average, but not with birth weight (17) or otitis risk in the child at age 2 (18). In Picardie, self-reported residence close $(<1 \mathrm{~km})$ to any crop field, likely to reflect more largely rural life than exposure to specific pesticides, was not associated with any of the birth outcomes considered (24).

None of these studies assessed pesticide exposure through diet, other than by considering the retrospectively self-reported proportion of organic food in the general diet, which is very limited as a means of assessing pesticide exposure $(17,24)$. 
Various herbicides and their metabolites, specifically known to have been used on corn crops and to have contaminated soil and water systems for several years, were determined in the prenatal urinary samples in the PELAGIE cohort. A possible increased risk of fetal growth restriction and small-head-circumference for sex and gestational age, and reduced head circumference at birth, were observed in association with urinary markers of direct exposure to atrazine and to metolachlor $\left(19^{*}\right)$. No association was observed with the urinary concentrations of other herbicides (alachlor, acetochlor), or those of dealkylated and hydroxylated metabolites of triazine likely to result from the environmental degradation of atrazine (19*). These findings are consistent with the absence of association between drinking-water contamination with these metabolites and birth outcomes, including preterm birth status, observed in the retrospective cohort $(26,27)$.

Due to possible neurotoxicity properties, prenatal exposure to OP and PYR insecticides, assessed through determinations of their common metabolites in maternal urine samples in the PELAGIE cohort, has been investigated in association with neurodevelopmental outcomes of the children at the age of six years $(20,21,22)$. No association was observed for either OP or PYR, other than a positive association between maternal urinary concentrations of diethylphosphate (DE) OP metabolites and the WISC-IV (Wechsler Intelligence Scale for Children) verbal comprehension scores of the children. DE metabolites are environmental degradation products that could be present in fruits and vegetables. We cannot, therefore, exclude the possibility that these urinary concentrations partly reflect the intake of fruit and vegetables, and that residual confounding might persist despite the statistical adjustment for this intake (22). The concentrations of OP and PYR metabolites measured from the urine samples of the children collected in the morning of the examination were related to the neuropsychological performance of the child in these studies, as secondary analyses $(20,22)$. Both WISC-IV verbal comprehension and working memory scores decreased with increasing urinary concentrations of PYR metabolites (3-PBA, common to several pyrethroid insecticides, and cis-DBCA, specific to deltamethrin) and working memory score decreased with increasing urinary concentrations of DE metabolites, suggesting a possible shortterm impact of these insecticides on some cognitive capacities. However, with this crosssectional design, we cannot exclude the possibility that a third factor, such as fatigue during the day, might affect both urinary excretion and cognitive capacities.

Parent-reported recurrent otitis media in children at age 2 was positively associated with prenatal urinary concentrations of both triazine dealkylated metabolites and OP insecticide metabolites. As pointed out by the authors, these findings are consistent with those of a few recent studies on mice, suggesting possible long-term effects on the immune system of prenatal exposure to atrazine or OP insecticides (18).

Clinical observations and animal experiments have shown that Ops may induce biological processes suggestive of insulin resistance. These findings are consistent with the increase in cordblood insulin levels observed with increasing prenatal urinary concentrations of OP metabolites in the PELAGIE cohort (23). This finding needs however to be replicated.

\section{Pesticides and childhood cancer in France}

Case-control studies, based on the high-quality French national registry of childhood 


\section{cancer}

Childhood leukemia is the commonest childhood cancer, and its main subtypes - acute lymphoblastic leukemia (ALL) and acute myeloid leukemia (AML) - generally occur before the age of five years. Childhood brain tumors (CBT) are the second most common childhood cancer. Neuroblastoma (NB) is a malignant embryonal tumor of the neural crest cells occurring almost exclusively in infancy and early childhood.

Two nationwide population-based case-control studies, ESCALE (Etude Sur les Cancers et les Leucémies de l'Enfant) and ESTELLE (Etude Sur les Tumeurs Embryonnaires, Leucémies et Lymphomes de l'Enfant), were performed with the support of the high-quality French national registry of childhood cancer (27). In both studies, the cases $(n>1,000)$ were children under the age of 15 years living in France at the time of their diagnosis with cancer in accordance with the $3^{\text {rd }}$ edition of the International Classification of Childhood Cancer. In ESCALE, cases were diagnosed over the 2003-2004 period, with leukemia, lymphoma, malignant CBT and NB. The ESTELLE period was more recent, 2010-2011, and other diagnoses were added such as benign CBT, Wilms' tumor and hepatoblastoma. In both studies, the controls $(n>1,000)$ were children free from cancer recruited from the French population by quota-sampling methods, by telephone, and with a similar age distribution to the cases for the study period concerned. Computer-assisted telephone interviews were conducted blind to case-control status, with a standardized questionnaire collecting diverse data, including maternal pesticide use at home and the main parental occupations during the pregnancy, for the index child. In ESTELLE, details for various periods of interest (around conception, during pregnancy, after birth) were also requested.

\section{The results: from individual studies to crucial international collaborations}

Based on an international coding system for jobs and the specific development of a job-exposure matrix, the Childhood Leukemia International Consortium (CLIC), a multinational collaboration of case-control studies on childhood leukemia including the ESCALE study, showed an association between maternal occupational exposure to agricultural or farm-related pesticides during pregnancy and the risk of AML (29), but not of ALL, with little evidence of betweenstudy heterogeneity. Paternal occupational exposure around conception was associated with a risk of ALL, but not of AML, with a high degree of heterogeneity between studies (29). An increased in the risk of NB associated with maternal occupational exposure to pesticides was also suggested in the ESCALE study, despite the small sample size (30).

The CLIC consortium showed an increase in the risks of both ALL and AML associated with maternal use, at home, of pesticide products during pregnancy and an increase in the risk of ALL with household pesticide use after birth $\left(31^{*}\right)$, with little evidence of heterogeneity between the 12 studies performed between 1980 and 2008, in North America, Europe and Australasia. Pooled analyses of the ESCALE and ESTELLE studies revealed an association between maternal domestic pesticide use during pregnancy and increased risk of both NB and CBT. A stronger association was suggested for indoor use and for products against insects, which were the most frequently used $(30,32)$.

\section{Conclusion}


The cohort studies mentioned above are original in France; to our knowledge, no other such study had already been conducted in France. Their findings have therefore improved our understanding in the French context of the possible effects of current-use pesticides on developmental health, from newborn to school-age child. According to them, we conclude that prenatal exposure to pesticides might have an impact on subclinical health parameters at birth, suggesting fetal growth alterations, and that no evidence of adverse neurodevelopmental outcomes at 6 years of age following to prenatal exposure to insecticides has been identified. According to the variety of pesticide exposure assessments, agricultural activities but also domestic usages should be considered in these adverse health associations. Cohort studies are a long-term research approach and only one, the PELAGIE cohort, has pursued the longitudinal follow-up until adolescence, offering the possibility to study the pesticide effects on puberty outcomes. However, assessment of exposure from single urine sample, as initially planned in the PELAGIE cohort, is subject to limitations for some non-persistent pesticides. More generally, chemical analyses and sample preparation may also constitute limitations when using exposure biomarkers. Perhaps even more importantly, although this remains to be assessed, long-term storage of urine, as required for cohort studies, may have limited some of these findings. Our understanding of matrices with 'cumulative' properties remains incomplete; however preliminary findings using meconium samples, as in the MecoExpo cohort (25,33), and maternal hair samples, as in the Elfe French national birth cohort (personal communication with R. Béranger), appear promising for the assessment of multiple exposure during fetal life.

The French studies on childhood cancer make consistent contributions to the dense existing literature including several high-quality meta-analyses for childhood leukemia. Unfortunately, these studies have not yet obtained sufficient evidence to infer a causal link, such as a "doseresponse" relationship, and no predominant biological mechanism involving one or a few possible pesticides with potentially different properties in addition to their carcinogenic effects has been suggested. Studies on maternal occupational exposure, which is infrequent, and childhood cancer, a rare outcome, should inevitably be pooled, making it difficult to perform a standardized quantitative or ordinal assessment of exposure. Efforts have been made to exclude differential recall bias in assessments of the household use of pesticide products (34) and to consolidate maternal self-reports as good proxies for residential pesticide exposure, through correlations with determinations of pesticide levels in household dust, for example $(35,36,37)$. The persistence of this association in many case-control studies from the early 1980s to the 2010s, and the consistency of findings are remarkable. They suggest that the causal pesticides, if indeed there are any, might have been consistently used in the composition of household products over time and in different countries.

In the field of epidemiological research on the effects of pesticides on human child health, exposure assessment is an important challenge and remains the most important limiting factor in the quality of evidence that observational studies can provide. We may adopt two approaches: assessments of exposure to specific molecules or families of molecules in order to improve pesticide regulations and assessments of the determinants and sources of exposure for possible future direct preventive actions among pregnant women. The first way is likely to rely on biomarkers of exposure for which sources and other determinants are not always identified. For example, with OP and PYR insecticides, several studies over a number of years were required to 
show that urinary concentrations predominantly reflect dietary exposure, rather than exposure through other sources, and the relative contributions of the various sources of human exposure remain unknown for most pesticides in current use. Pesticide determinations in other biological matrices, such meconium and maternal hair, which hold promise for studies focusing on the prenatal period, should thus be complemented by studies of their determinants. For this biomonitoring approach, multiresidue analyses can deal with mixtures of selected pesticides, and should be encouraged, even though not yet integrated into the regulatory system. The second approach is another way to deal with realistic human exposure to mixtures, even if unidentified. Knowledge of the molecules used should be integrated into the exposure assessment. For example, the composition of each household pesticide product available on the market should be known. This should become possible soon in France, through the national initiative Pesti'Home (16).

In conclusion, French studies have clearly contributed to the literature on the role of pesticide exposure on child health. To our knowledge, such studies are lacking in many other European countries, despite the existence of high-quality mother-child cohorts (www.birthcohorts.net). Studies on the effects of fungicides on child health are scarce, particularly in France where fungicides are heavily used in agriculture. Finally, previous studies have focused heavily on exposure during pregnancy and not enough on exposure during childhood, despite the ubiquitous exposure of children to several types of pesticides $(12,22,37)$.

\section{References}

1. European Commission. 2017. EU Pesticides database. Available: http://ec.europa.eu/food/plant/pesticides_en. Last visit: March 28th, 2017

2. ** ANSES, Exposition de la population générale aux résidus de pesticides en France : Synthèse et recommandations du comité d'orientation et de prospective scientifique de l'observatoire des résidus de pesticides, ORP. Rapport scientifique, 2010.

Of high importance. This report is the first in France to provide a thorough overview of the existing data describing the exposure to current-used pesticides of the general population, from the possible exposure sources including environmental contamination data to the human biomonitoring data.

3. Cordier S, Bouquet E, Warembourg C, Massart C, Rouget F, Kadhel P, Bataille H, Monfort C, Boucher O, Muckle G, Multigner L. Perinatal exposure to chlordecone, thyroid hormone status and neurodevelopment in infants: the Timoun cohort study in Guadeloupe (French West Indies). Environ Res. 2015 Apr;138:271-8.

4. Costet N, Pelé F, Comets E, Rouget F, Monfort C, Bodeau-Livinec F, Linganiza EM, Bataille H, Kadhel P, Multigner L, Cordier S. Perinatal exposure to chlordecone and infant growth. Environ Res. 2015 Oct;142:123-34. 
5. Hervé D, Costet N, Kadhel P, Rouget F, Monfort C, Thomé JP, Multigner L, Cordier S. Prenatal exposure to chlordecone, gestational weight gain, and birth weight in a Guadeloupean birth cohort. Environ Res. 2016 Nov;151:436-444.

6. Aubertot JN, Barbier JM, Carpentier A, Gril JJ, Guichard L, Lucas P et al. Pesticides, agriculture et environnement. Réduire l'utilisation des pesticides et limiter leurs impacts environnementaux. Expertise scientifique collective, synthèse du rapport, INRA et Cemagref (France), 64 p ; 2005.

7. CGDD, Commissariat général au Développement durable. Service de l'observation et des statistiques. Ministère de la Transition écologique et Solidaire. Indicateurs de la transition écologique vers un développement durable - Comparaisons internationales. Mai 2017 (http://www.statistiques.developpementdurable.gouv.fr/fileadmin/documents/Produits_editoriaux/Publications/Datalab/2017/Data lab-19-INTEDD-comparaisons-internationales-mai-2017.pdf)

8. CGDD, Commissariat général au Développement durable. Service de l'observation et des statistiques. Ministère de la Transition écologique et Solidaire. Les pesticides dans les cours d'eau français en 2013. Chiffres \& statistiques $n^{\circ} 697$ - novembre 2015 (http://www.statistiques.developpementdurable.gouv.fr/fileadmin/documents/Produits_editoriaux/Publications/Chiffres_et_statisti ques/2015/chiffres-stats697-pesticides-dans-cours-deau2013-novembre2015.pdf)

9. www.ATMO-france.org

10. Nougadère A, Sirot V, Kadar A, Fastier A, Truchot E, Vergnet C, Hommet F, Baylé J, Gros P, Leblanc JC. Total diet study on pesticide residues in France: levels in food as consumed and chronic dietary risk to consumers. Environ Int. 2012 Sep 15;45:135-50.

11. https://www.anses.fr/en/content/total-diet-studies-tdss

12. Bouvier G, Blanchard O, Momas I, Seta N. Environmental and biological monitoring of exposure to organophosphorus pesticides: application to occupationally and nonoccupationally exposed adult populations. J Expo Sci Environ Epidemiol. 2006 Sep;16(5):417-26.

13. Chevrier C, Petit C, Limon G, Monfort C, Durand G, Cordier S. Biomarqueurs urinaires d'exposition aux pesticides des femmes enceintes de la cohorte Pélagie réalisée en Bretagne (2002-2006). Bulletin Epidémiologique Hebdomadaire. 16 Juin 2009, Edition spéciale.

14. Fréry N, Saoudi A, Garnier R, Zeghnoun A, Falq G, Guldner L. Exposition de la population française aux polluants de l'environnement - Volet environnemental de l'Étude nationale nutrition santé - Premiers résultats. Saint-Maurice: Institut de veille sanitaire; 2010: $12 \mathrm{p}$. 
15. Dereumeaux C, Saoudi A, Pecheux M, Berat B, de Crouy-Chanel P, Zaros C, Brunel S, Delamaire C, le Tertre A, Lefranc A, Vandentorren S, Guldner L. Biomarkers of exposure to environmental contaminants in French pregnant women from the Elfe cohort in 2011. Environ Int. 2016 Dec;97:56-67.

16. https://www.anses.fr/fr/content/pesti\%E2\%80\%99home-1\%E2\%80\%99\%C3\%A9tudesur-les-utilisations-domestiques-des-pesticides

17. Petit C, Blangiardo M, Richardson S, Coquet F, Chevrier C, Cordier S. Association of environmental insecticide exposure and fetal growth with a Bayesian model including multiple exposure sources: the PELAGIE mother-child cohort. Am J Epidemiol. 2012 Jun 1;175(11):1182-90.

18. Buscail C, Chevrier C, Serrano T, Pelé F, Monfort C, Cordier S, Viel JF. Prenatal pesticide exposure and otitis media during early childhood in the PELAGIE mother-child cohort. Occup Environ Med. 2015 Dec;72(12):837-44.

19. * Chevrier C, Limon G, Monfort C, Rouget F, Garlantézec R, Petit C, Durand G, Cordier S. Urinary biomarkers of prenatal atrazine exposure and adverse birth outcomes in the PELAGIE birth cohort. Environ Health Perspect. 2011 Jul;119(7):1034-41.

Of importance. This study evaluates for the first time with exposure biomarkers the association between atrazine exposure and child health; it has suggested possible adverse impact on fetal growth, especially on head circumference.

20. Viel JF, Warembourg C, Le Maner-Idrissi G, Lacroix A, Limon G, Rouget F, Monfort C, Durand G, Cordier S, Chevrier C. Pyrethroid insecticide exposure and cognitive developmental disabilities in children: The PELAGIE mother-child cohort. Environ Int. 2015 Sep;82:69-75.

21. Viel JF, Rouget F, Warembourg C, Monfort C, Limon G, Cordier S, Chevrier C. Behavioural disorders in 6-year-old children and pyrethroid insecticide exposure: the PELAGIE mother-child cohort. Occup Environ Med. 2017 Mar;74(4):275-281.

22. Cartier C, Warembourg C, Le Maner-Idrissi G, Lacroix A, Rouget F, Monfort C, Limon G, Durand G, Saint-Amour D, Cordier S, Chevrier C. Organophosphate Insecticide Metabolites in Prenatal and Childhood Urine Samples and Intelligence Scores at 6 Years of Age: Results from the Mother-Child PELAGIE Cohort (France). Environ Health Perspect. 2016 May;124(5):674-80.

23. Debost-Legrand A, Warembourg C, Massart C, Chevrier C, Bonvallot N, Monfort C, Rouget F, Bonnet F, Cordier S. Prenatal exposure to persistent organic pollutants and organophosphate pesticides, and markers of glucose metabolism at birth. Environ Res. 2016 Apr;146:207-17. 
24. Mayhoub F, Berton T, Bach V, Tack K, Deguines C, Floch-Barneaud A, Desmots S, Stéphan-Blanchard E, Chardon K. Self-reported parental exposure to pesticide during pregnancy and birth outcomes: the MecoExpo cohort study. PLoS One. 2014 Jun 20;9(6):e99090.

25. Tourneux P, Mayhoub F, Haraux E, Deguines C, Berton T, Lestremeau F, Gondry J, Bach V, Chardon K. MecoExpo Cohort: Using Meconium to Estimate In Utero Exposure to Pesticides in Newborn Infants in Picardy. Rev. Méd. Périnat. 2014 ; 6:122-133

26. Migeot V, Albouy-Llaty M, Carles C, Limousi F, Strezlec S, Dupuis A, Rabouan S. Drinking-water exposure to a mixture of nitrate and low-dose atrazine metabolites and small-for-gestational age (SGA) babies: a historic cohort study. Environ Res. 2013 Apr;122:58-64.

27. Albouy-Llaty M, Limousi F, Carles C, Dupuis A, Rabouan S, Migeot V. Association between Exposure to Endocrine Disruptors in Drinking Water and Preterm Birth, Taking Neighborhood Deprivation into Account: A Historic Cohort Study. Int J Environ Res Public Health. 2016 Aug 9;13(8).

28. Clavel J, Goubin A, Auclerc MF, Auvrignon A, Waterkeyn C, Patte C, et al. 2004. Incidence of childhood leukaemia and non-Hodgkin's lymphoma in France: National Registry of Childhood Leukaemia and Lymphoma, 1990-1999. Eur J Cancer Prev 13:97103.

29. Bailey HD, Fritschi L, Infante-Rivard C, Glass DC, Miligi L, Dockerty JD, Lightfoot T, Clavel J, Roman E, Spector LG, Kaatsch P, Metayer C, Magnani C, Milne E, Polychronopoulou S, Simpson J, Rudant J, Sidi V, Rondelli R, Orsi L, Kang AY, Petridou E, Schüz J. Parental occupational pesticide exposure and the risk of childhood leukemia in the offspring: findings from the childhood leukemia international consortium. Int J Cancer. 2014 Nov 1;135(9):2157-72.

30. Rios P, Bailey HD, Lacour B, Valteau-Couanet D, Michon J, Bergeron C, Boutroux H, Defachelles AS, Gambart M, Sirvent N, Thebaud E, Ducassou S, Orsi L, Clavel J. Maternal use of household pesticides during pregnancy and risk of neuroblastoma in offspring. A pooled analysis of the ESTELLE and ESCALE French studies (SFCE). Cancer Causes Control. 2017 Oct;28(10):1125-1132.

31. * Bailey HD, Infante-Rivard C, Metayer C, Clavel J, Lightfoot T, Kaatsch P, Roman E, Magnani C, Spector LG, Th Petridou E, Milne E, Dockerty JD, Miligi L, Armstrong BK, Rudant J, Fritschi L, Simpson J, Zhang L, Rondelli R, Baka M, Orsi L, Moschovi M, Kang AY, Schüz J. Home pesticide exposures and risk of childhood leukemia: Findings from the childhood leukemia international consortium. Int J Cancer. 2015 Dec 1;137(11):2644-63.

Of importance. This study is the fruit of international collaborative efforts, and has allowed to replicate previous results of individual studies. It shows that this collaborative 
effort should be maintained and improved for better exposure assessment across involved studies.

32. Vidart d'Egurbide Bagazgoïtia N, Bailey HD, Orsi L, Lacour B, Guerrini-Rousseau L, Bertozzi AI, Leblond P, Faure-Conter C, Pellier I, Freycon C, Doz F, Puget S, Ducassou $\mathrm{S}$, Clavel J. Maternal residential pesticide use during pregnancy and risk of malignant childhood brain tumors: A pooled analysis of the ESCALE and ESTELLE studies (SFCE). Int J Cancer. 2018 Feb 1;142(3):489-497.

33. Berton T, Mayhoub F, Chardon K, Duca RC, Lestremau F, Bach V, Tack K. Development of an analytical strategy based on LC-MS/MS for the measurement of different classes of pesticides and theirs metabolites in meconium: application and characterisation of foetal exposure in France. Environ Res. 2014 Jul;132:311-20.

34. Slusky DA, Metayer C, Aldrich MC, et al. Reli- ability of maternal-reports regarding the use of household pesticides: experience from a case-con- trol study of childhood leukemia. Cancer Epide- miol 2012;36:375-80.

35. Deziel NC, Colt JS, Kent EE, Gunier RB, Reynolds P, Booth B, Metayer C, Ward MH. Associations between self-reported pest treatments and pesticide concentrations in carpet dust. Environ Health. 2015 Mar 25;14:27.

36. Trunnelle KJ, Bennett DH, Tancredi DJ, Gee SJ, Stoecklin-Marois MT, Hennessy-Burt TE, Hammock BD, Schenker MB. Pyrethroids in house dust from the homes of farm worker families in the MICASA study. Environ Int. 2013 Nov;61:57-63.

37. Glorennec P, Serrano T, Fravallo M, Warembourg C, Monfort C, Cordier S, Viel JF, Le Gléau F, Le Bot B, Chevrier C. Determinants of children's exposure to pyrethroid insecticides in western France. Environ Int. 2017 Jul;104:76-82. 
Table 1: Recent epidemiological studies relating the current-use pesticide exposure and child health in France

\begin{tabular}{|c|c|c|c|c|c|c|c|}
\hline Study name & $\begin{array}{l}\text { Study design, } \\
\text { population }\end{array}$ & Health outcomes of interest & Outcomes assessment & Nature of exposure & Exposure assessment & $\begin{array}{l}\text { Other data collected to } \\
\text { eliminate confounding }\end{array}$ & $\begin{array}{l}\text { Refer } \\
\text { ences }\end{array}$ \\
\hline \multirow[t]{7}{*}{$\begin{array}{l}\text { PELAGIE } \\
\text { cohort }\end{array}$} & \multirow{7}{*}{$\begin{array}{l}\text { Mother-child } \\
\text { cohort } \\
3421 \text { pregnant } \\
\text { women enrolled } \\
\text { before the 19th } \\
\text { week of gestation } \\
\text { by gynecologists, } \\
\text { obstetricians and } \\
\text { ultrasonographers, } \\
\text { in Brittany from } \\
2002 \text { to February } \\
2006 \text {; and their } \\
\text { children followed } \\
\text { at different ages }\end{array}$} & $\begin{array}{l}\text { Intrauterine growth restriction at } \\
\text { birth }(\mathrm{n}=180)\end{array}$ & $\begin{array}{l}\text { Modeled within the cohort according } \\
\text { to gestational age, sex, parity, } \\
\text { maternal weight, height, and age. }\end{array}$ & $\begin{array}{l}\text { From surrounding } \\
\text { agricultural activities }\end{array}$ & $\begin{array}{l}\text { For targeted pesticides }{ }^{*} \text { : in maternal urine samples } \\
\text { collected in early pregnancy at inclusion, and in urine } \\
\text { samples from the child (first-morning voids), according } \\
\text { to a case-cohort design with a subcohort ( } n=601) \\
\text { randomly selected from the liveborn singleton cohort. } \\
\text { Using both the national general census in } 2000 \text { at the } \\
\text { scale of the municipality, and satellite-based images } \\
\text { (2003-2006) of soil occupancy by corn and cereals } \\
\text { crops (scale: } 250 \mathrm{~m} \text { ), combined with local surveys of } \\
\text { agricultural pesticide use. }\end{array}$ & $\begin{array}{l}\text { Self-administered } \\
\text { questionnaire at inclusion } \\
\text { and during the various } \\
\text { childhood follow-up visits } \\
\text { (family social and } \\
\text { demographic } \\
\text { characteristics, diet, and } \\
\text { lifestyle) }\end{array}$ & $17-23$ \\
\hline & & $\begin{array}{l}\text { Small-head-circumference for sex } \\
\text { and gestational age at birth } \\
(n=105)\end{array}$ & $\begin{array}{l}\text { Defined according to according to } \\
\text { French reference curves. }\end{array}$ & $\begin{array}{l}\text { Household uses of } \\
\text { pesticide products during } \\
\text { pregnancy }\end{array}$ & $\begin{array}{l}\text { From self-administered questionnaire completed by } \\
\text { the parents at } 2 \text { years of age of the child: seven types } \\
\text { of uses }\end{array}$ & & \\
\hline & & Major congenital malformations & $\begin{array}{l}\text { Diagnosed in live-born infants by } \\
\text { maternity-unit pediatricians } \\
\text { (including specific examination for } \\
\text { male genital abnormalities). }\end{array}$ & Organic food intake & $\begin{array}{l}\text { From self-administered questionnaire at } 2 \text { years of } \\
\text { age: using food frequency questionnaire and the } \\
\text { organic/conventional origin of various food groups }\end{array}$ & & \\
\hline & & $\begin{array}{l}\text { Glucose metabolism at birth } \\
(n=268)\end{array}$ & Measured in cord blood samples & & & & \\
\hline & & Otitis at 2 years of age & $\begin{array}{l}\text { Assessed using the number of otitis } \\
\text { episodes (at least one, or at least } \\
\text { three) self-reported in the parents' } \\
\text { questionnaire }(n=1505)\end{array}$ & & & & \\
\hline & & Child's behavior at 6 years of age & $\begin{array}{l}\text { Assessed from the parent-reported } \\
\text { Strengths and Difficulties } \\
\text { Questionnaire ( } n=1404)\end{array}$ & & & & \\
\hline & & $\begin{array}{l}\text { Neuropsychological assessment at } \\
6 \text { years of age }(n=287)\end{array}$ & $\begin{array}{l}\text { Conducted at home by } \\
\text { psychologists for the verbal } \\
\text { comprehension and working } \\
\text { memory domain (WISC-IV subtests) }\end{array}$ & & & & \\
\hline \multirow[t]{5}{*}{$\begin{array}{l}\text { MecoExpo } \\
\text { cohort }\end{array}$} & \multirow{5}{*}{$\begin{array}{l}\text { Mother-child } \\
\text { cohort } \\
993 \text { mother-child } \\
\text { pairs enrolled at } \\
\text { birth from } 16 \\
\text { maternity clinics in } \\
\text { Picardy, from } \\
\text { January } 2011 \text { and } \\
\text { January } 2012\end{array}$} & $\begin{array}{l}\text { Birth weight }(\mathrm{g}) \text {, length }(\mathrm{cm}) \text {, head } \\
\text { circumference }(\mathrm{cm}) \text { and gestational } \\
\text { age (weeks of gestation) }\end{array}$ & $\begin{array}{l}\text { Extracted from medical records at } \\
\text { birth. }\end{array}$ & $\begin{array}{l}\text { Parental occupations } \\
\text { with possible pesticide } \\
\text { uses, during pregnancy }\end{array}$ & $\begin{array}{l}\text { From self-administered questionnaire for the mothers } \\
\text { at the maternity clinics after the delivery }\end{array}$ & $\begin{array}{l}\text { Self-administered } \\
\text { questionnaire at inclusion } \\
\text { (family social and }\end{array}$ & 24 \\
\hline & & $\begin{array}{l}\text { 'Low birth weight' }(n=42) \text { and 'Low } \\
\text { birth length' }(n=56)\end{array}$ & $\begin{array}{l}\text { Modeled within the cohort according } \\
\text { to gestational age, sex, parity, } \\
\text { maternal weight, height, and age. }\end{array}$ & $\begin{array}{l}\text { From surrounding } \\
\text { agricultural activities }\end{array}$ & $\begin{array}{l}\text { From self-administered questionnaire after the } \\
\text { delivery: question of living proximity to crops }\end{array}$ & $\begin{array}{l}\text { demographic } \\
\text { characteristics, diet, and } \\
\text { lifestyle) }\end{array}$ & \\
\hline & & $\begin{array}{l}\text { Small-head-circumference for sex } \\
\text { and gestational age }(n=34)\end{array}$ & $\begin{array}{l}\text { Defined according to French } \\
\text { reference curves }\end{array}$ & $\begin{array}{l}\text { Household uses of } \\
\text { pesticide products during } \\
\text { pregnancy }\end{array}$ & $\begin{array}{l}\text { From self-administered questionnaire after the } \\
\text { delivery: five types of uses }\end{array}$ & & \\
\hline & & Preterm birth & $\begin{array}{l}\text { Defined as a duration of gestation } \\
<37 \text { weeks. }\end{array}$ & Organic food intake & $\begin{array}{l}\text { From self-administered after the delivery: using food } \\
\text { frequency questionnaire and the organic/conventional } \\
\text { origin of various food groups }\end{array}$ & & \\
\hline & & & & Biomarkers & $\begin{array}{l}\text { Measurement of targeted pesticides in meconium } \\
\text { samples (on-going) }\end{array}$ & & \\
\hline \multirow[t]{3}{*}{$\begin{array}{l}\text { Retrospective } \\
\text { cohort }\end{array}$} & \multirow{3}{*}{$\begin{array}{l}\text { Retrospective } \\
\text { cohort } \\
20,270 \text { births in } \\
\text { Deux-Sèvres } \\
\text { between } 2005 \text { and } \\
2009(n=24,316 \\
\text { until 2010) }\end{array}$} & Birth weight (g) & $\begin{array}{l}\text { From the mandatory infant health } \\
\text { certificates }(2005-2009 ; n=11,446)\end{array}$ & \multirow[t]{3}{*}{$\begin{array}{l}\text { Herbicide exposure from } \\
\text { drinking water, during } \\
\text { the second trimester of } \\
\text { pregnancy }\end{array}$} & \multirow[t]{3}{*}{$\begin{array}{l}\text { Routine measurements in drinking water* by the } \\
\text { French regional Health Agency, at the municipality } \\
\text { scale (for towns with only one drinking-water supplier; } \\
>80 \% \text { ) }\end{array}$} & \multirow[t]{3}{*}{$\begin{array}{l}\text { Routine determinations of } \\
\text { nitrates in drinking water } \\
\text { and a few items of data } \\
\text { from infant birth certificates }\end{array}$} & \multirow[t]{3}{*}{26,27} \\
\hline & & $\begin{array}{l}\text { Small-for-gestational-age }(n=985 \\
8.6 \%)\end{array}$ & $\begin{array}{l}\text { Calculated from the French } \\
\text { reference growth curves (exclusion } \\
\text { of multiple births, newborns with } \\
\text { birth defects or delivered by } \\
\text { cesarean section, or living in towns } \\
\text { with more than one supplier of } \\
\text { drinking water) }\end{array}$ & & & & \\
\hline & & Preterm birth $(n=586 ; 4.3 \%)$ & $\begin{array}{l}\text { Defined as birth at }<37 \text { weeks of } \\
\text { gestation }(2005-2010)\end{array}$ & & & & \\
\hline
\end{tabular}
organophosphate insecticides and their metabolites) 
